Canadian Journal of Educational Administration and Policy
Revue canadienne en administration et politique de l'éducation

CJEAP

\title{
Cote-Meek, S., \& Moeke-Pickering, T. (2020). Decolonizing and Indigenizing Education in Canada
}

\section{Candace Brunette-Debassige}

Numéro 197, 2021

URI : https://id.erudit.org/iderudit/1083337ar

DOI : https://doi.org/10.7202/1083337ar

Aller au sommaire du numéro

\section{Éditeur(s)}

Department of Educational Administration, University of Saskatchewan

\section{ISSN}

1207-7798 (numérique)

Découvrir la revue

\section{Citer ce compte rendu}

Brunette-Debassige, C. (2021). Compte rendu de [Cote-Meek, S., \& Moeke-Pickering, T. (2020). Decolonizing and Indigenizing Education in Canada]. Canadian Journal of Educational Administration and Policy / Revue canadienne en administration et politique de l'éducation, (197), 111-112. https://doi.org/10.7202/1083337ar d'utilisation que vous pouvez consulter en ligne. 
Canadian Journal of Educational Administration and Policy, 197, 111-112

\title{
Cote-Meek, S., \& Moeke-Pickering, T. (2020). Decolonizing and Indigenizing Education in Canada. Canadian Scholars Press.
}

\author{
Reviewed by: Candace Brunette-Debassige, Western Univerisity
}

For anyone genuinely interested in pushing institutional commitments to Indigenization toward meaningful transformative change, Decolonizing and Indigenizing Education in Canada is a must-read. This latest from Canadian Scholars Press offers no simple checklist approach to reconciliation work - indeed, the word reconciliation itself is problematized throughout many of the book's chapters - and it will most definitely help to build your critical understanding and praxis around reconciliation work in education in Canada. Co-editors Sheila Cote-Meek, whose work in Indigenous education spans over thirty years and long precedes the release of the Truth and Reconciliation Commission (TRC), and Taima Moeke-Pickering, who has written extensively about decolonization strategies, social change, and Indigenous wellbeing, are firmly grounded in Indigenous education and leadership theory and praxis. They skillfully curate sixteen chapters covering a breadth of perspectives on the possibilities, complexities, and tensions of Indigenizing and decolonizing education in the post-reconciliation era.

Cote-Meek's introductory chapter reminds readers of the profound role colonization played in the growth of academia in Canada, and of its effects on Indigenous Peoples and Indigenous ways of knowing which, she asserts, have been "effectively debased and devalued." Cote-Meek concedes that the academy continues to act as "a central site of ongoing colonialism" ( $\mathrm{p} . \mathrm{xv}$ ) and is in need of transformative change - change that is disruptive and that can move "organizations into drastically different ways of being, doing and working" (p. xvii).

The book's 15 remaining chapters, by a wide variety of Indigenous and non-Indigenous scholars and educators including academics, Elders, and students, address broad conceptual and praxis-centered debates about leading transformative decolonial change in higher education. The chapters are organized under two overarching themes, the first, starting rightfully so, with a section on Indigenous Epistemologies and the second on Decolonizing Postsecondary Institutions.

In the Indigenous Epistemologies section, authors describe exemplars of how Indigenous land-based pedagogies are upheld in education, for example through a Cree culture camp offered at the First Nations University of Canada, a First Nations controlled university-college that serves the academic, cultural, and spiritual needs of First Nations' students. Another chapter offers compelling strategies for advancing Métis education. Yet another chapter reports on the establishment of an Indigenous doctoral student relational network to resist academic conventions and advance Indigenous collectivity, relationality, and ethics in Indigenous research.

The Decolonizing Postsecondary Institutions section offers important insights into the limits of attempts to decolonize the academy. In chapter seven, for example, Lynn Lavallee denounces the widespread use of the term reconciliation as a neocolonial term. She questions institutional commitments toward decolonization stating that they are "overly ambitious" and involve asymmetrical micro-level power relations that often do not serve Indigenous Peoples. Emily Grafton and Jérôme Melancon similarly critically interrogate the power interplay that occurs in processes of interpreting Indigenizing and decolonizing commitments, arguing that the meanings of those commitments change "depending on 
Indigenous and settler identity and the colonial position of those participating in the [practices]" (p. 141). While many authors critique the tendency of universities to showcase themselves as beacons of reconciliation, other Indigenous writers such as Chantal Fiola courageously describe how, despite institutional proclamations, Indigenous peoples continue to be marginalized through precarious work conditions. Toward the end of this second section, two chapters focus on the challenges faculty members experience when instituting mandatory course requirements in university contexts.

Decolonizing and Indigenizing Education in Canada dedicates intellectual space to a cross section of Indigenous research approaches including Indigenous storytelling, poetry, and reflective writing as well as case study and survey research. I was struck by how each author carefully and complexly situates their work within their own identities, their relationships to settler colonialism, and their connections to Indigenous land and place, thus speaking clearly to the significance of positionality in Indigenous education research. Many described the recurring challenges they face in teaching in the academy, and add their voices to widespread criticism of the ways in which institutions take up the terms Indigenization, decolonization, and reconciliation - the latter being the most contentious term. These authors offer a chorused call for institutions to become more critical of their discursive moves. Indigenous Peoples' voices are strong and clear in this compilation as they identify, expose, and critique the settler colonialism that continues to exist in, mark, mar, dominate their everyday lives and institutional practices.

One of my favourite aspects of this collection is the reflective questions, key terms, and further readings offered at the end of each chapter, a feature particularly useful for instructors and serious practitioners. Indeed, this collection will make an especially relevant text for anyone attempting to respond to the TRC's calls to action in their teaching at undergraduate or graduate levels, or in their research in Indigenous education, policy, leadership, Indigenous Studies, and other health, social sciences, and humanities areas.

During a time of increasing social inequities and political unrest, Decolonizing and Indigenizing Education in Canada is an important contribution to understanding the advances and pitfalls of the reconciliation movement in Canada. Most importantly, it will contribute to an appreciation of Indigenous Peoples' distinct place in higher education and their unique rights to determine higher educational aims. I highly recommend this book to all CJEAP members. As leaders and scholars in the academy, we share a particular responsibility to familiarize ourselves with the features and critiques of the Indigenization and decolonization movement. 